\title{
Quality of Service Using Partial Least Square (PLS)
}

\author{
Panji Priya Sahita ${ }^{1}$, Julianus Hutabarat ${ }^{2}$, Nelly Budiharti ${ }^{3}$ \\ 1,2,3 Industrial Engineering Masters Program, National Institute of Technology, \\ Malang 65245, Indonesian
}

\begin{abstract}
Service quality is very closely related to customer satisfaction, the higher the quality of service provided, the higher the level of customer satisfaction obtained. The problem in this research is the presence of complaints from various customers of elevator maintenance service users which results in not achieving customer satisfaction. The purpose of this study is to find out what are the expectations needed by the customer to achieve customer satisfaction assisted by the PLS program.Questionnairedistributed the five objects of the research site then conducted the $R$ Square, Q-Square, F-Square and T-square tests to find out the relationship and influence between variables to customer satisfaction. In the R-Square test the relationship of variables in the model is $56.9 \%$ and 43.1\% based on variables outside the actual performance model, the expected relationship between variables in the model is $72.7 \%$ and $27.3 \%$ comes from outside the model. Q-square test on the actual performance model of $32.7 \%$ and $52.85 \%$ on the expectation model. In the F-square test the actual performance of the biggest influence variable reliability of 0.277 on the expected influence of the reliability variable of 0.336 (large effect size) tangible 0.066 and responsiveness of 0.115 (medium effect size). In the $\mathrm{T}$ Square test the actual performance variable reliability was 0,000 and the expected tangible variable was 0.037 , reliability was 0,000 , responsiveness was 0.003 . After testing it can be seen that the company has not been able to provide the expected customer satisfaction.
\end{abstract}

Keyword:- PLS, Service Quality, Customer Satisfaction, Variables,

\section{INTRODUCTION}

Elevators are vertical transportation that is needed in high-rise buildings today to be more efficient and effective. PT. Balistha Gapala Nandya is an official company of Fuji HD distributor engaged in the procurement of elevators and escalators. The purpose of this research is to find out what are the expectations needed by the customer to achieve customer satisfaction of the service users. There are several complaints about elevator maintenance services, namely inBangil Hospital, Soedono Madiun Hospital, Paru Jember Hospital, Darsono Pacitan Hospital, dr. Sayyidiman Magetan Hospital so that he did research to find out the expectations needed by the customer to achieve customer satisfaction. The variables on service quality can be seen in the Fishbone Fig 1 below [1]:

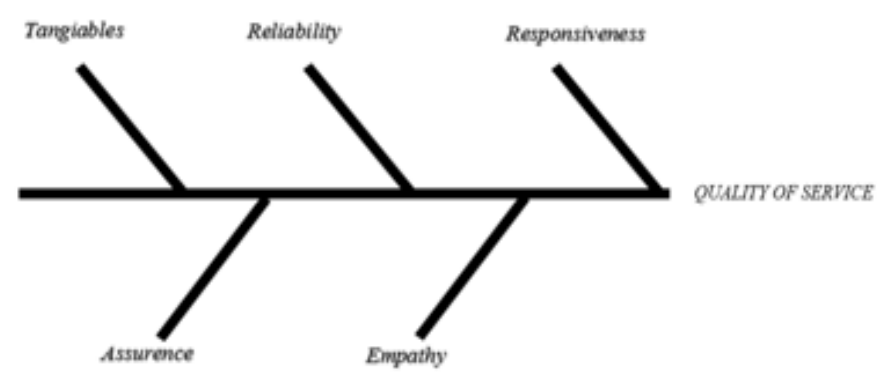

Fig 1:- Fishbone Diagram

In the fishbone diagram above it can be seen that there are five variables that affect service quality, namely tangible, reliability, responsiveness, assurance, empathy [2].

\section{RESEARCH METHODS}

This research uses quantitative data types, and its processing uses descriptive statistical methods, namely statistics used to analyze data by describing data that has been collected as it [3]. This research was conducted at five hospital agencies located in East Java, namely Bangil Hospital, Soedono Madiun Hospital, Paru Jember Hospital, Darsono Pacitan Hospital, dr.Sayyidiman Magetan Hospital as consumers who use elevator maintenance services. The population in this study were all hospital employees in the study object and the elevator user unit. The sample in this study were employees at the Hospital Infrastructure and Facilities Agency (IPSRS) at each of the hospital's agencies and user elevators.

Data collection techniques in this study by conducting a survey at each place of research so as to know the shape, physical, characteristics of something to be studied [4]. Conducting observations to retrieve data directly in the field to find out the service conditions at the institution that were the object of this study and distributing questionnaires was carried out to obtain data from the customer [5] about complaints on quality provided by elevator maintenance services. Analysis of the data in this study is the questionnaire results processed by the PLS program to determine the effect of service quality variables on customer satisfaction. 
ISSN No:-2456-2165

\section{ANALYSIS OF RESULTS}

\section{$>\quad R$-Square Test}

The R-Square test is used to determine the relations between variables to customer satisfaction [6]. The relation of tangible variables, reliability, responsiveness, assurance, empathy to customer satisfaction using PLS software can be seen in Table 1 below:

\begin{tabular}{|c|c|c|c|}
\hline No & Model & Variable & $R$-Square \\
\hline 1 & $\begin{array}{c}\text { Actual } \\
\text { performance }\end{array}$ & $\begin{array}{c}\text { customer } \\
\text { satisfaction }\end{array}$ & 0,569 \\
\hline 2 & Hope & $\begin{array}{c}\text { customer } \\
\text { satisfaction }\end{array}$ & 0,727 \\
\hline
\end{tabular}

Table 1:- R-Square Test

In Table 1 above it can be seen that the actual performance of the R-Square value of 0.569 or $56.9 \%$ of the relationship variables in the model and the expectation of 0.727 or $72.7 \%$ of the variables in the model.

\section{Q Q-Square Test}

Q-Square test is used to find out the predictive value relevant to a model [7]. The predictive values relevant to this study can be seen in Table 2 below:

\begin{tabular}{|c|c|c|c|}
\hline No & Model & Variabel & $Q$-Square \\
\hline 1 & $\begin{array}{c}\text { Actual } \\
\text { performance }\end{array}$ & $\begin{array}{c}\text { Customer } \\
\text { Satisfaction }\end{array}$ & 0,3237 \\
\hline 2 & Hope & $\begin{array}{c}\text { Customer } \\
\text { Satisfaction }\end{array}$ & 0,5285 \\
\hline
\end{tabular}

Table 2:- Q-Squre Test

From Table 2 it can be seen that the predictive value relevant to actual performance is 0.3237 or $32.37 \%$ and has a medium effect size. While the expectation is 0.5285 or $52.85 \%$ and has a large effect size.

\section{F-Square Test}

The F-Square value of the model is used to determine the effect size of the exogenous latent variable [8]. The actual F-Square test results can be seen in Table 3 below:

\begin{tabular}{|c|c|c|}
\hline NO & INDICATOR & $\begin{array}{c}\text { CUSTOMER } \\
\text { SATISFACTION }\end{array}$ \\
\hline 1 & Tangibel & 0,023 \\
\hline $\mathbf{2}$ & Reliability & $\mathbf{0 , 2 7 7}$ \\
\hline 3 & Responsiveness & 0,010 \\
\hline 4 & Assurance & 0,022 \\
\hline
\end{tabular}

Table 3:- F-Square Test Actual Performance

From Table 3 F-Square actual performance results can be seen that if the reliability indicator has an f-square of 0.277 and is included in the large effect size because it is above 0.15 , while the other three indicators have a low effect size. We can see the F-Square test in Table 4 below:

\begin{tabular}{|c|c|c|}
\hline NO & INDICATOR & $\begin{array}{c}\text { CUSTOMER } \\
\text { SATISFACTION }\end{array}$ \\
\hline 1 & Tangibel & 0,066 \\
\hline $\mathbf{2}$ & Reliability & $\mathbf{0 , 3 3 6}$ \\
\hline 3 & Responsiveness & 0,115 \\
\hline 4 & Assurance & 0,025 \\
\hline \multicolumn{3}{|c|}{ Table 4:- F-Square Test Hope }
\end{tabular}

F-Square expected reliability of 0.336 and included in the large effect size while 2 other indicators such as tangible, responsiveness, have a medium effect size and assurance indicators have a low effect size. F-square test results which show that the reliability indicator has a large effect size on customer satisfaction.

\section{> T-Square Test}

$\mathrm{T}$-square functions to test how the influence of each independent variable individually to the dependent variable [9]. This test can be seen by comparing t-counts with ttables. The results of the T-Square actual performance test can be seen in Table 5 below:

\begin{tabular}{|c|c|c|c|}
\hline & $\begin{array}{c}\text { Original } \\
\text { Sample } \\
(O)\end{array}$ & $\begin{array}{c}T- \\
\text { Statistics }\end{array}$ & $\begin{array}{c}P \\
\text { Value }\end{array}$ \\
\hline $\begin{array}{c}\text { Tangibel } \rightarrow \text { Customer } \\
\text { Satisfaction }\end{array}$ & 0,1243 & 1,383 & 0,166 \\
\hline $\begin{array}{c}\text { Reliability } \rightarrow \text { Customer } \\
\text { Satisfaction }\end{array}$ & 0,540 & 4,688 & 0,000 \\
\hline $\begin{array}{c}\text { Responsiveness } \rightarrow \text { Customer } \\
\text { Satisfaction }\end{array}$ & 0,083 & 0,950 & 0,342 \\
\hline $\begin{array}{l}\text { Assurance } \rightarrow \text { Customer } \\
\text { Satisfaction }\end{array}$ & 0,1456 & 1,270 & 0,204 \\
\hline
\end{tabular}

Table 5:- T-Square Test Actual Performance

From the results above it can be interpreted that the 3 variables do not affect customer satisfaction. While the Realiabity variable of 0,000 below the percentage of error values which indicates that the reliability variable is very influential with customer satisfaction on actual performance. T-Square Test results in the hope we can see in Table 6 below:

\begin{tabular}{|c|c|c|c|}
\hline & $\begin{array}{c}\text { Origina } \\
l \\
\text { Sample } \\
(O)\end{array}$ & $\begin{array}{c}T- \\
\text { Statistic } \\
\text { On }\end{array}$ & $\begin{array}{c}P \\
\text { Valu } \\
e\end{array}$ \\
\hline $\begin{array}{c}\text { Tangibel } \rightarrow \text { Customer } \\
\text { Satisfaction }\end{array}$ & $\mathbf{0 , 1 6 3}$ & $\mathbf{2 , 0 9 2}$ & $\mathbf{0 , 0 3 7}$ \\
\hline $\begin{array}{c}\text { Reliability } \rightarrow \text { Customer } \\
\text { Satisfaction }\end{array}$ & $\mathbf{0 , 5 0 1}$ & $\mathbf{4 , 7 6 0}$ & $\mathbf{0 , 0 0 0}$ \\
\hline $\begin{array}{c}\text { Responsiveness } \rightarrow \text { Custome } \\
\text { r Satisfaction }\end{array}$ & $\mathbf{0 , 2 3 2}$ & $\mathbf{3 , 0 2 3}$ & $\mathbf{0 , 0 0 3}$ \\
\hline $\begin{array}{c}\text { Assurance } \rightarrow \text { Kepuasan } \\
\text { Kelanggan }\end{array}$ & 0,118 & 1,117 & 0,265 \\
\hline
\end{tabular}

Table 6:- T-Square Test Hope 
From Table 6 above it can be seen that the tangible, reliability, responsiveness variables affect customer satisfaction. While the assurance variable has no effect on customer satisfaction. After doing R-Square, Q-Square, FSquare and T-Squre Tests, it can be seen that customers who use elevator maintenance services are not satisfied with the company's performance. It can be seen from the results of T-Square that customers have 3 expected variables, namely tangible, reliability, and responsiveness while the company only provides reliability. The company should prioritize and improve on the tangiable and responsiveness and maintain the reliability variable in order to meet the expectations of customers.

\section{CONCLUSION}

Conclusion of the results of the study to determine customer satisfaction, namely:

$>$ Customer elevator service users are not satisfied with the company's performance.

$>$ The company can only satisfy customers on the variable reliability, while the tangible and responsiveness of the customer is not satisfied.

\section{REFERENCES}

[1]. Farminta, Veron, Sigit Mujiharjo, Karona Cahya Susena. 2015. Analisis Kualitas Pelayanan Industri Jasa Olah Raga Dengan Menggunakan Metode Servqual dan Importence Performance Analysis (IPA). Jurnal Argo Industri Vol.5 No.1 hlm.57-74

[2]. Alaan, Yunus. 2016. Pengaruh Service Quality (Tangible, Empathy, Reliability, Responsiveness, Assurance) Terhadap Coustumer Satisfaction: Penelitian Pada Hotel Selera Bandung. Jurnal Manajemen. Vol.15. No.2. hlm. 255-277

[3]. Kuntoro, Antonius Yadi, Moh. Ari Hasan, Dedi Dwi Saputra, Dwiza Riyana. 2019. Analisis Faktor Yang Mempengaruhi Kepuasan Pelanggan Fix Pay Menggunakan SEM dan PLS. Junal Informatika. Vol.6. No.1. hlm122-133.

[4]. Rozandy, Rizki Aditiya, Imam Santoso, Shintya Atica Putri. 2017. Analisis Variabel-Variabel Yang Memepengaruhi Tingkat Adopsi Teknologi Dengan Metode Patrial Least Square (Studi Kasus Pada Sentra Industri Tahu Desa Sendang, Kec. Banyakan, Kediri ). Jurnal Industrial Vol.1. No.3. hlm.147-158.

[5]. Astuti, Dewi, Febi Nur Salisah. 2016. Analisis Kualitas Pelayanan E-Commerce Terhadap Kepuasan Pelanggan Menggunakan Metode EServqual (Studi Kasus : Lejel Home Pekanbaru). Jurnal Rekayasa dan Manajemen Sistem Informasi. Vol.2. No.1. hlm 2460-8181

[6]. Sudjana. 2016. Metode Statistika. Bandung: PT.Tarsito

[7]. Puung, Florensia Karunia, Ahmad Fudholi, dan Basu Swastha Darmesta. 2015. Analisis Pengaruh Kualitas Pelayanan dan Kepuasan Loyalitas Pelanggan di Salon dan SPA. Jurnal Manajemen dan Pelayanan Farmasi. Vol.4 No. 2 hlm. 105-110
[8]. Deoranto, Panji, Maria Ulfa, Mas'ud Effendi. 2015. Analisis Pengaruh Experiental Marketing Terhadap Kepuasan Pelanggan Menggunakan PLS DI Duta Katering. Jurnal Agroindustri dan Lokarya Nasional. Vol.1 No.1. hlm.6-14

[9]. Handayani, Naniek Utami, Haryo Santoso, Adhitiya Ichwal Pratama. 2018. Faktor-Faktor Yang Mempengaruhi Peningkatkan Daya Saing Klaster Mebel Di Kabupaten Jepara. Jurnal Teknik Industri Vol. 13. No. 1. hlm. 22-30 